\title{
Career Choice Tendency of State Senior High School Students in Industry 4.0 Era
}

\author{
(Kecenderungan Pilihan Karier Siswa Sekolah Menengah Atas Negeri di Era Revolusi Industri
} 4.0)

\author{
Zulfianti Rosyida Zahro, Arbin Janu Setiyowati*, Irene Maya Simon \\ Department of Guidance and Counseling, Faculty of Education, Universitas Negeri Malang, \\ Semarang Street. No 5. Malang, East Java, 65145 Indonesia \\ *corresponding author, e-mail: arbin.janu.fip@um.ac.id
}

Article received: April $5^{\text {th }} 2020$; revised: June $29^{\text {th }} 2020$; accepted: July $9^{\text {th }} 2020$

\begin{abstract}
This study aims to describe the career choice tendency of state senior high school students in the industry 4.0 era. This research is quantitative descriptive research, in the form of a percentage, involving 236 students as the participants. The sample was chosen using cluster random sampling technique. For the instrument, this research used a questionnaire of students' career choice tendency in the industry 4.0 era. The obtained data were analyzed using percentage descriptive statistics. The findings reveal that $93 \%$ of senior high school students in Malang city tend to choose a career in the business and repair services sector, then followed by $89 \%$ of students who select the trading and government administration sector. This study can be fundamental and primary data for school counselors in providing guidance and counseling services in the career field, such as career information services. This service belongs to one of the students' consideration to carefully plan their career to achieve a bright future.
\end{abstract}

Keywords: career choice; industry 4.0; guidance and counseling services

\begin{abstract}
Abstrak: Penelitian ini bertujuan untuk mendeskripsikan kecenderungan pilihan karier siswa sekolah menengah atas negeri pada era revolusi industri 4.0. Penelitian ini merupakan penelitian kuantitatif deskriptif dalam bentuk persentase yang menggunakan sampel, dan melibatkan 236 siswa. Metode pemilihan sampel menggunakan teknik cluster random sampling. Instrumen yang digunakan dalam penelitian ini adalah kuesioner kecenderungan pilihan karier siswa di era revolusi industri 4.0. Analisis data yang digunakan adalah teknik analisis data statistik deskriptif persentase. Temuan menunjukkan siswa sekolah menengah atas negeri se-Kota Malang di era revolusi industri 4.0 memiliki kecenderungan pilihan karier pada sektor layanan bisnis dan perbaikan dengan persentase $93 \%$ yang diikuti oleh sektor perdagangan dan pemerintahan yang masing-masing mendapatkan persentase $89 \%$. Studi ini menjadi data dasar dan utama bagi konselor sekolah dalam memberikan layanan bimbingan dan konseling di bidang karier seperti layanan informasi karier yang merupakan komponen perencanaan individual siswa agar dapat merencanakan pilihan karier secara matang dan mendapatkan masa depan yang gemilang.
\end{abstract}

Kata kunci: pilihan karier; industri 4.0; layanan bimbingan dan konseling 


\section{INTRODUCTION}

The senior high school students in 12th grade are teenagers at the secondary developmental stage between 15-17 years old. At this stage, significant physical and psychological transformations occur, along with the attainment of compulsory developmental tasks. Besides, students also encounter a tentative career development stage (Batubara, 2013). The tentative career development period turns students to recognize work requirements, as well as their interests and skills for their career choice before they get into the stage of a realistic period. During the tentative career period, the students are demanded to be capable of deciding career choices. However, a study conducted by Pramudi (2015) identifies that $73.40 \%$ of students possess low career decision-making skills. Besides, according to research carried out by Wulandari et al., (2016), the tendency profile of students' career choice is situated in a conventional career. This career categorization is based on Holland's career classification that is practical, restrained, semi-conservative, structured, and well-ordered. The example of a job in a conventional career is office and administration (secretary, accountant, file clerk) workers, as well as the ones related to those jobs (Tarsidi, 2007).

The tendency of conventional career choices carries various difficulties for students to adapt to the career in the industry 4.0 era, which is mostly correlated to sufficient technology and the internet. Consequently, currently, many YouTubers, vloggers, or even gamers appear. Additionally, a study conducted by Mckinsey Global Institute (Manyika et al., 2017) mentions that half of the activities completed in this world can be automated using the existing or future technology. There are $60 \%$ or at least one-third of constitutional works that can be automated. This indicates a need for changes and transformation in workplaces, suitable for the workers. A similar study also suggests that during the industry 4.0 era, 23 million workers are possibly replaced by automated technology until 2030 in Indonesia (Das et al., 2019).

According to the literature review that compares studies with similar discussion, a study that investigates students' career choice tendency, from the perspective of career choice changes, in the industry 4.0 era, has not been carried out. Most of the studies investigate the effect of the industry era toward teenagers or commonly known as $Z$ generation (Adiansah et al., 2019), involving their behavior, perception, and concept toward the career in industry 4.0 era (Mowforth, 2018; Bencsik, 2016; Ozkan \& Solmaz, 2015). If the students' career choice tendency can be recognized and predicted, a manifestation of the secondary career selection process (orientation) after readiness, then it becomes the fundamental point that aids school counselors to assist students in going to the further career selection process since students frequently face difficulties during the career selection process (Kulcsár, Dobrean, \& Gati, 2020).

Guidance and counseling is an integral part of education that aims to facilitate the students' optimum development. Meanwhile, school counselor holds the responsibility to provide the proper and precise services for students, primarily in the industry 4.0 era, that signals changes in career development. This study aims to discover the career choice tendency of senior high school students' across Malang city in the industry 4.0 era. This study is essential to be carried out as an initial step of school counselors to design the guidance and counseling program that facilitates senior high school students' career development in the industry 4.0 era.

\section{METHOD}

This research uses a descriptive research design (Arikunto, 2013) with a quantitative approach. There are three data collection steps for descriptive research, namely: (1) preparation stage or preliminary study, (2) implementation stage or research data collection, and (3) management stage.

This study was carried out in state senior high schools across Malang city. The selected participants were 236 twelfth graders. The participants were determined using a cluster sampling technique based on the school zonation system, as well as a random sampling technique. The schools were chosen through consideration of the parents' social-economic background. The selected schools are State Senior High School 7, 8, 6, and 10 .

The instrument used in this study was a questionnaire on career choice tendency of state senior high school students across Malang city in the industry 4.0 era. The instrument was developed from an outline established based on studies related to changes in career choices. Each item on the questionnaire 
was adjusted to the features of the industry 4.0 era. Even if the mention of the employment sector seems to be traditional, this research has issued career choices that are consistent with the industry 4.0 era in each of the questionnaires item, such as being vlogger and Youtuber on the entertainment sector.

Those career choices are summarized in the employment sectors. A study carried out by McKinsey Global Institute sectors threaten to be finished, namely the agriculture sector $(-55.9 \%)$, manufacturing sector $(-3.6 \%)$, and mining sector (-1.3\%) (Manyika et al., 2017). The industry 4.0 era is constituted from the integration of Cyber-Physical Systems (CPS), a technology that combines the real and virtual world, and Internet of Things and Service (IoT and IoS), a device concept that capable of communicating with each other through the internet in the industrial or other processes (Kagermann et al., 2013). This instrument was expected to completely illustrate the career tendency of state senior high school students across Malang city in the industry 4.0 era.

The instrument uses the Guttman scale with scoring categories (yes/no) (Sugiyono, 2015). The validity and reliability of the scale should be tested to assure its valid and reliable results (Arikunto, 2013). The validity test was completed using the biserial correlation (RBIs) (Djaali, 2000); meanwhile, the reliability test was carried out using the Cronbach Alpha formula (Sujianto, 2009). After the validity and reliability test were conducted, 140 from 180 items are acknowledged to be valid and reliable.

The data obtained in this study are the data on the career choice tendency of state senior high school students across Malang in the industry 4.0 era. The data were analyzed using a quantitative descriptive percentage technique. The career choice tendency analysis was carried out for each employment sector to discover the employment sector commonly preferred by students. The analysis was carried out using Formula (1), in which $\mathrm{Nm}$ represents the number of items chosen in each employment sector, $\mathrm{Mn}$ is the number of respondents choosing the items in each employment sector, $\mathrm{N}$ is the total number of items in each sector, and $\mathrm{M}$ is the number of respondents.

$$
\text { Percentage of each employment sector }=((\mathrm{Nm} \times \mathrm{Mn}):(\mathrm{N} \times \mathrm{M})) \times 100 \%
$$

\section{RESULTS}

The obtained results are in the form of percentages for each employment sector selected by students. Then, the results of the career choice tendency of state senior high school students across Malang city in the industry 4.0 era were sorted, from the highest to the lowest percentage, as presented in Table 1. Table 1 demonstrates that the highest percentage is obtained by business and repair service $(93 \%)$, followed by trade and government service that conveyed the same rate of $89 \%$. Therefore, the career choice tendency of state senior high school students across Malang city is dominated by those three employment sectors. The graphic of the questionnaire results is illustrated in Figure 1.

Table 1. Percentage of Each Employment Sector

\begin{tabular}{ccc}
\hline No. & Employment Sector & Percentage (\%) \\
\hline 1 & Business and repair services & 93 \\
2 & Trade and retail services & 89 \\
3 & Government services & 89 \\
4 & Professional services & 87 \\
5 & Telecommunications & 85 \\
6 & Education services & 85 \\
7 & Construction services & 80 \\
8 & Healthcare services & 78 \\
9 & Household chores & 76 \\
10 & Utilities & 74 \\
11 & Entertainment & 72 \\
12 & Financial services & 72 \\
13 & Transportation services & 68 \\
\hline
\end{tabular}




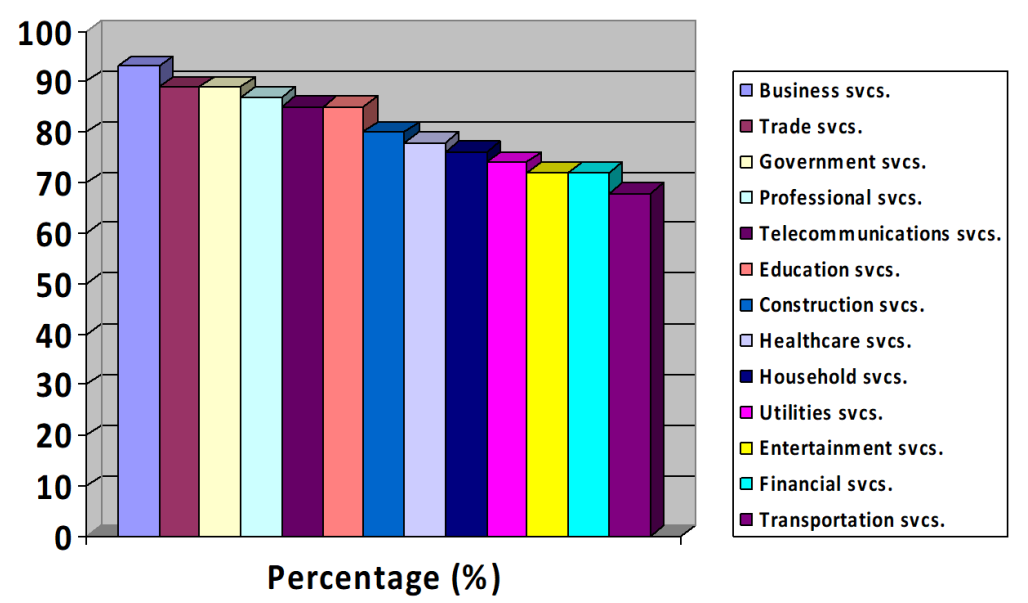

Figure 1. Graphic of Each Employment Sector Percentage

\section{DISCUSSION}

The students in the 12th grade of senior high school, born between 1995-2010, are commonly known as $\mathrm{Z}$ generation (Bencsik, 2016). These students have career choice characteristics that are aware of the internet and technology, passionate (Adiansah et al., 2019), do not have problems with gender and age, like challenges, do not like traditional expression (Ozkan \& Solmaz, 2015), and capable of collaborating with a partner from every generation (Bencsik, 2016). The preliminary study suggests that 12th grade senior high school students prefer careers in the entertainment sector, such as creating YouTube or vlog content, as well as actualize themselves based on their hobby and interest. However, the findings of this study show different results. The results identify that the students have a tendency of career choice in the business and repair sector (93\%), followed by retail and government sector $(89 \%)$. Therefore, it indicates that the present entertainment sector, such as Youtuber and vlogger, have not been perceived as promising career by senior high school students across Malang.

The business and repair sector has the highest tendency percentage of $93 \%$. According to the questionnaire answers, the items mostly selected in this sector are the culinary business. This finding is in line with an opinion expressed by Levita G. Supit, the general leader of the Association of Indonesia Franchise and License, that food and beverage businesses will dominate the 2020 industry since culinary belongs to people's primary needs. The types of culinary predicted to have the excellent opportunity are processed chicken, noodles, and coffee shops. Besides, based on the fast-changing of local and world culinary creativity, fast food will also encounter continuous development and innovation. Additionally, the franchise is one of the models to expand a business that aims to improve the profit (Gim, Choi, \& Jang, 2019). The results of this study illustrate that the continuous promotion in the culinary sector will be a positive model for the development of students' careers. It is in accordance with vicarious learning theory that emphasizes learning from other people's experiences (Bandura, 1986).

During the industry 4.0 era, social media has been a promotion tool massively used to develop a business. This comes from the practical and significant effects brought by social media on consumer's purchasing power (Putri, 2016; Priambada, 2015; Zuhroh \& Pamungkas, 2016; Indika \& Jovita, 2017). Considering this effect, 149 students choose to be a store owner item that optimizes the marketplace to accelerates the selling. Thus, the trade and retail sector attains the second position with a percentage of $89 \%$, along with the government sector. On the government sector, 137 students select various items, such as being labor offices worker who complete and manage government officials.

There are four fundamental factors that influence an individual in deciding their career choice, namely: interest, self-image, personality, and social background (Subekhi, 2012). The interest, selfimage, and personality factors belong to internal factors, while the social background is the external factor. Besides, career choice is also affected by the parents-children relation. A study on $\mathrm{Z}$ generation career concept carried out to students of Coventry University reveals that parents' support on career decision and self-fulfillment autonomy, along with environment information, aid students' concept of 
career (Mowforth, 2018). Children learn their relationship with parents so that it brings career choices based on their needs and environment. One of the effects of the environment is the stereotype or perception of a particular job.

In addition, career choice is also influenced by a comparison between one-self with the stereotype of a job, both from the job's acceptance and rejection perspective (Tarsidi, 2007). It is linear to the stereotype of the business and trade sector as a powerful way to attain a prosperous life. Even with the massive growth of technology, the development of e-commerce in Indonesia reaches $78 \%$ (Kominfo, 2019).

The government sector is labeled as a promising sector with proper payment, the authority to rule a policy, various subsidies, and proper life, along with being respected in the society's social system. During the civil servant recruitment in 2019, 197,111 positions were opened (Arnani, 2019), and 4,196,339 people applied for them (Idhom, 2019). The number of applicants is significantly higher than the number of positions opened. This phenomenon follows the job popularity shift, which formerly in the entertainment sector to be in the government or political sector (Setyorini, 2019), as well as the trade sector (Sari, 2019). Thus, those three sectors dominate the career choice tendency.

Other than the social perception and the recent phenomena, a study completed by Ozkan \& Solmaz (2015) in world business, economy, and management conference on $Z$ generation and their perspective toward a career that involve 276 college students reveal a $77 \%$ score for $Z$ generation's tendency to work with technology to achieve their goal. That number is lower than the previous $Y$ generation that obtains an $81 \%$ score. This can somehow explain the current career choice of the $\mathrm{Z}$ generation that tends to be in government than the conventional sector. Besides, $Z$ generation also prefers home office $(19 \%)$, a more modern workplace with adjustable rooms (38\%), and to be a manager who listens to ideas and respects the opinion form their colleagues (61\%). In the last aspect, $\mathrm{Z}$ generation is suitable for working in the business sector since they can excellently lead the business and create a supportive environment. These factors influenced the selection of three industries that dominated students' career choices in the industry 4.0 era.

The industry 4.0 era is correlated with automation and artificial intelligent (AI) concepts. This is not a new concept, but the rapid growth of technology has enabled machines to complete various tasks. The world society, including Indonesian, has started to shift its payment using an electronic payment platform. Based on research carried out by McKinsey Global Institute (2017), a lot of works have been replaced and automated by Cyber-Physical System (CPS) and the Internet of Things and Services (IoT and IoS).

In Indonesia, the abolishment and shift of workers have reached 23 million, possibly being automated until 2030 (Das et al., 2019). It is marked by the collapse of several employment sectors during 2016, with the most significant bankruptcy experienced by the transportation sector due to the emergence of online-based transportation. The turnover decreased in the transportation sector, primarily at land transportation, which reaches $30-50 \%$. The industry 4.0 era carries a massive disruption effect (innovation) for the old stakeholder that triggers conflicts across the world (Kasali, 2017).

The concern appears in every part of human life, especially in the rise of unemployment. In fact, those jobs are not disappeared; they adjusted to the innovation and changes. According to a study conducted by Mckinsey (2019), 23 million jobs are being replaced by 27-46 million new jobs in Indonesia that positively contribute to the country's economy in the next decade. Besides, ILO (International Labour Organization) tries to improve the investment in human skills, working institutions, along with feasible and sustainable jobs as a response to this phenomenon (ILO, 2019).

With these shifting phenomena, changes of career choice, industry 4.0 era's characteristics and demand, as well as students' career choice tendency in business, trade, and government sector, school counselors hold a considerable responsibility to accommodate, develop, and prepare students who are responsive to industry 4.0 era, since the educational institution is one of the essential pillar for the success in this era (Das et al., 2019). This students' career choice tendency data can be a primary and fundamental data for guidance and counseling service, especially in the career field. Career field services for students can be in the form of further career selection process (information) since students mostly face difficulties in deciding their career choice (Kulcsár et al., 2020). This service is formulated in the semester and annual program for guidance and counseling courses. 
On the primary component, the school counselors can provide group guidance service using a problem-solving technique with career problems in the industry 4.0 era. This enables students to assess the changes within themselves and their environment to compose their choice, decision, and proper adaptation (Romlah, 2013). Besides, the cultivation of creative and innovative behavior in students is critical to be carried out in every service provided by the school counselor. Considering the importance of the work field interpersonal communication, communication is one of the essential components that should be owned by students. Based on the research finding, the role-playing strategy has been proven effective in improving interpersonal communication skills (Wicaksono, 2013).

In addition to role play strategy, the school counselor can also use the technology in providing guidance and counselor service, such as by using educational cinema techniques, so that students are not easily bored. This educational cinema has also been confirmed to be efficient in establishing students' skills, even in the psychological aspects that support the learning process in school (Auliyah \& Flurentin, 2016; Simon, 2016). Consequently, through those services, the school counselor can develop students' soft skills, other than their academic skills.

The school counselor can also provide information services related to the comparison between the current employment, universities, and future career prospect. This service is the basic attempt to provide placement service in students' individual planning component. School counselors are happy to accompany and help students in deciding their next step be taken. Other than the guidance service, the school counselor can also provide career counseling service for the issues that require immediate solvency. Additionally, a school counselor needs to possess proper cultural skills to facilitate students to decide their career choice.

Cultural skills are required to comprehend the effect of students' cultural backgrounds on their career choice (Setiyowati et al., 2019). Other than the cultural skill, the counselor also has to possess digital and technology skills (Fadli, Ifdil, \& Amalianita, 2019). Since the process of changes is better than the result (Dweck, 2006), the school counselor also needs to carefully consider things in the planning, implementing, and evaluating the completed program and services. This idea will be formulated once someone possesses a growth mindset that appreciates process and struggle. As someone who teaches those values, the school counselor has to maintain them.

In relation to the students' career choice tendency on business and repair service, along with trade and government service, then school counselor is required to encourage students to be more creative and innovative through adjustments toward technology advancement through the services structured in the counseling and guidance program in the semester or annual program. This aims to allow students to adapt and participate in the competition in the industry 4.0 era. Even if the students' career choice tendency is dominated by those three sectors, there is still a possibility that the career choice changes since it will continuously develop (Batubara, 2013). Besides, students are still in the teenage ages that allow changes, including in career choice, as their social interaction becomes broader (Santrock, 2012).

\section{CONCLUSION}

The most prominent career choice tendency of state senior high school students across Malang city in the industry 4.0 era is identified in the business sector (93\%), trade sector (89\%), and government sector $(89 \%)$. This research finding can be fundamental and primary data for the school counselor to establish a program for senior high school students, especially those in the career field, so that they can thoroughly plan their careers and reach their success in the future.

\section{REFERENCES}

Adiansah, W., Setiawan, E., Nurdini, W., \& Hery, K. (2019). Person in environment remaja pada era revolusi industri 4.0. Jurnal Pekerjaan Sosial, 2, 47-60.

Arikunto, S. (2013). Prosedur penelitian; Suatu pendekatan praktik. Jakarta: PT. Rineka Cipta.

Arnani, M. (2019). Rekrutmen CPNS 2019 buka 197.111 formasi, ini perinciannya. from: https://www.kompas. com.

Auliyah, A., \& Flurentin, E. (2016). Efektifitas penggunaan media film untuk meningkatkan empati siswa kelas VII SMP. Jurnal Kajian Bimbingan dan Konseling, 1(2), 19-26. https://doi.org/10.17977/um001v1i12016p019 
Bandura, A. (1986). Social foundations of thought and action. Englewood Cliffs, NJ.

Batubara, J. (2013). Perkembangan dan pemilihan karier menurut Ginzberg dan implikasinya terhadap bimbingan dan konseling. Jurnal Konseling dan Pendidikan, 1(1), 43-47. https://doi.org/10.29210/1800

Bencsik, A., Horváth-Csikós, G., \& Juhász, T. (2016). Y and Z Generations at Workplaces. Journal of Competitiveness, 8(3), 90-106.

Das, K., Wibowo, P., Chui, M., Agarwal, V., \& Lath, V. (2019). Automation and the future of work in indonesia: jobs lost, jobs gained, jobs changed. McKinsey \& Company.

Djaali, D. (2000). Pengukuran dalam pendidikan. Jakarta: Program Pascasarjana.

Dweck, C. S. (2006). Mindset: The new psychology of success. New York: Random House Publishing.

Fadli, R. P., Ifdil, I., \& Amalianita, B. (2019). Peluang dan tantangan bimbingan karir di sekolah menengah kejuruan pada era revolusi industri 4.0. Jurnal EDUCATIO, 5(2), 102-108.

Gim, J., Choi, K., \& Jang, S. (Shawn). (2019). Do franchise firms manage their earnings more? Investigating the earnings management of restaurant firms. International Journal of Hospitality Management, 79, 70-77. https://doi.org/10.1016/j.ijhm.2018.12.013

Idhom, A. M. (2019). Cara mengecek jumlah pendaftar CPNS 2019 setiap formasi di SSCN. from: https://www. tirto.id

ILO. (2019). Work for a brighter future: Global commission on the future of work. Geneva: International Labour Organization.

Indika, D. R \& Jovita, C. (2017). Media sosial instagram sebagai sarana promosi untuk meningkatkan minat beli konsumen. Jurnal Bisnis dan Terapan, 1, 25-32.

Kasali, R. (2017). Disruption. Jakarta: PT Gramedia Pustaka Utama.

Kominfo. (2019). Kemkominfo: Pertumbuhan e-commerce Indonesia capai 78 persen.

Kulcsár, V., Dobrean, A., \& Gati, I. (2020). Challenges and difficulties in career decision making: Their causes, and their effects on the process and the decision. Journal of Vocational Behavior, 116(July 2018), 103346. https:// doi.org/10.1016/j.jvb.2019.103346

Manyika, J., Lund, S., Chui, M., Bughin, J., Woetzel, J., Batra, P., Ko, R., \& Sanghvi, S. (2017). Jobs lost, jobs gained: What the future of work will mean for jobs, skills, and wages. Brussels, San Fransisco \& Shanghai.

Mowforth, S. (2018). Exploring the career conceptions of generation-z students at Coventry University: A project report for HECSU. England.

Ozkan, M., \& Solmaz, B. (2015). The changing face of the employees-generation Z and their perceptions of work (a study applied to university students). Procedia Economics and Finance, 26, 476-483. https://doi. org/10.1016/S2212-5671(15)00876-X

Pramudi, H. (2015). Kemampuan pengambilan keputusan karir siswa kelas XI di SMA Negeri 1 Kutasari Purbalingga. Bimbingan dan Konseling, 2.

Priambada, S. (2015). Manfaat penggunaan media Sosial pada usaha kecil menengah (UKM). In Seminar Nasional Sistem Informasi Indonesia (pp. 41-46). Surabaya: Institut Teknologi Sepuluh Nopember.

Putri, C. S. (2016). Pengaruh media sosial tehadap keputusan pembelian konsumen Cherie melalui minat beli. PERFORMA: Jurnal Manajemen dan Start-up Bisnis, 1, 594-603.

Romlah, T. (2013). Teori dan praktek bimbingan kelompok. Malang: Universitas Negeri Malang.

Sari, F. M. (2019). 6 artis yang sukses terjun ke bisnis. from: https://www.liputan6.com

Setiyowati, Arbin Janu., Pali, M., Wiyono, B. B., \& Triyono, T. (2019). Structural model of counseling competence. Cakrawala Pendidikan, 38(1), 45-62.

Setyorini, T. (2019). 7 artis yang pilih jadi PNS, ada yang jadi pejabat tinggi. from: https://www.merdeka.com

Simon, I. M. (2016). Cinema-education techniques for optimizing guidance and counseling services in school. In 2nd ICET Theme: "Improving The Quality of Education And Training Through Strengthening Networking (pp. 448-451). Malang: Faculty of Education, State University of Malang.

Subekhi, D. (2012). Pengantar manajemen sumber daya manusia. Jakarta: Prestasi Pustaka Jakarta.

Sugiyono. (2015). Metode penelitian pendidikan; pendidikan kuantitatif, kualitatif, dan R\&D. Bandung: Alfabeta CV Bandung.

Sujianto, A. E. (2009). Aplikasi statistik dengan SPSS. Jakarta: Prestasi Pustaka.

Tarsidi, D. (2007). Teori perkembangan karir. 
Wicaksono, G. (2013). Penerapan teknik bermain peran dalam komunikasi interpersonal siswa. Mahasiswa Bimbingan Konseling, 1, 61-78.

Wulandari, A. D., Dharmayana, I. W., \& Suprapti, A. (2016). Profil kecenderungan pemilihan minat karir berdasarkan tipe kepribadian siswa SMA se-Kota Bengkulu. Jurnal TRIADIK, 15(2), 30-42.

Zuhroh, S \& Pamungkas, A. P. (2016). Pengaruh promosi di media sosial dan word of mouth terhadap keputusan pembelian (Studi kasus pada Kedai Bontacos, Jombang). Komunikasi, 10(2), 145-160. 